\title{
New record of the Midas free-tailed bat (Mops midas) from the Arabian Peninsula (Mammalia: Chiroptera)
}

\author{
Petr Benda ${ }^{1,2}$, Mohammed Shobrak ${ }^{3,4}$ \& Jiří Šmíd ${ }^{1,2}$ \\ ${ }^{1}$ Department of Zoology, National Museum (Natural History), Václavské nám. 68, \\ 11579 Praha 1, Czech Republic \\ ${ }^{2}$ Department of Zoology, Charles University, Viničná 7, 12843 Praha 2, Czech Republic \\ ${ }^{3}$ Department of Biology, Faculty of Science, Taif University, Saudi Arabia \\ ${ }^{4}$ Saudi Wildife Authority, Prince Saud Al Faisal Research Center, Taif, Saudi Arabia
}

Benda P., Shobrak M. \& Jiří Šmíd J., 2019: New record of the Midas free-tailed bat (Mops midas) from the Arabian Peninsula (Mammalia: Chiroptera). - Journal of the National Museum (Prague), Natural History Series 188: 147-150.

\begin{abstract}
A new record of the Midas free-tailed bat, Mops midas (Sundevall, 1843), from Saudi Arabia is presented. This new record is the northernmost occurrence point of this rare bat in Arabia (ca. $160 \mathrm{~km} \mathrm{NNW}$ of the closest previous site) and also within its entire distribution range.
\end{abstract}

Key words: Midas free-tailed bat, Mops midas, Saudi Arabia, Middle East, Afro-tropics

Received: November 25, 2019| Accepted: December 6, 2019 | Issued: December 13, 2019

The Midas free-tailed bat, Mops midas (Sundevall, 1843), is a large molossid bat distributed widely but patchily in the savannas of sub-Saharan Africa, from Senegal to Eritrea and from Namibia to Sudan (Dunlop 1999, Coterill \& Happold 2013). Beyond Africa, it occurs widely in Madagascar while only rarely in western Arabia (Harrison \& Bates 1991, Dunlop 1999). Among the African bats which extend in their distribution to Arabia, only the Midas freetailed bat is known solely from Saudi Arabia; other true Afro-tropical faunal elements occur more or less widely in Yemen and some also reach the Dhofar region in south-western Oman (Harrison \& Bates 1991, Benda et al. 2011, 2013).

The first record of the Midas free-tailed bat from Arabia was mentioned by Hayman (1954: 288); he reported two adult females acquired by the collection of the British Museum (Natural History) (BMNH, currently the Natural History Museum London) as follows: "The two [bats] now received were collected by G. Popov in western Arabia, near the north Yemen border, at 500 feet above sea level on 26 January 1949". The exact site nor the country of collection were not given in this report. Nevertheless, Harrison (1964) and Nader (1975) regarded this record to originate from south-western Saudi Arabia and Nader (1975) included the Midas free-tailed bat into his checklist of bats of the Kingdom of Saudi Arabia. 


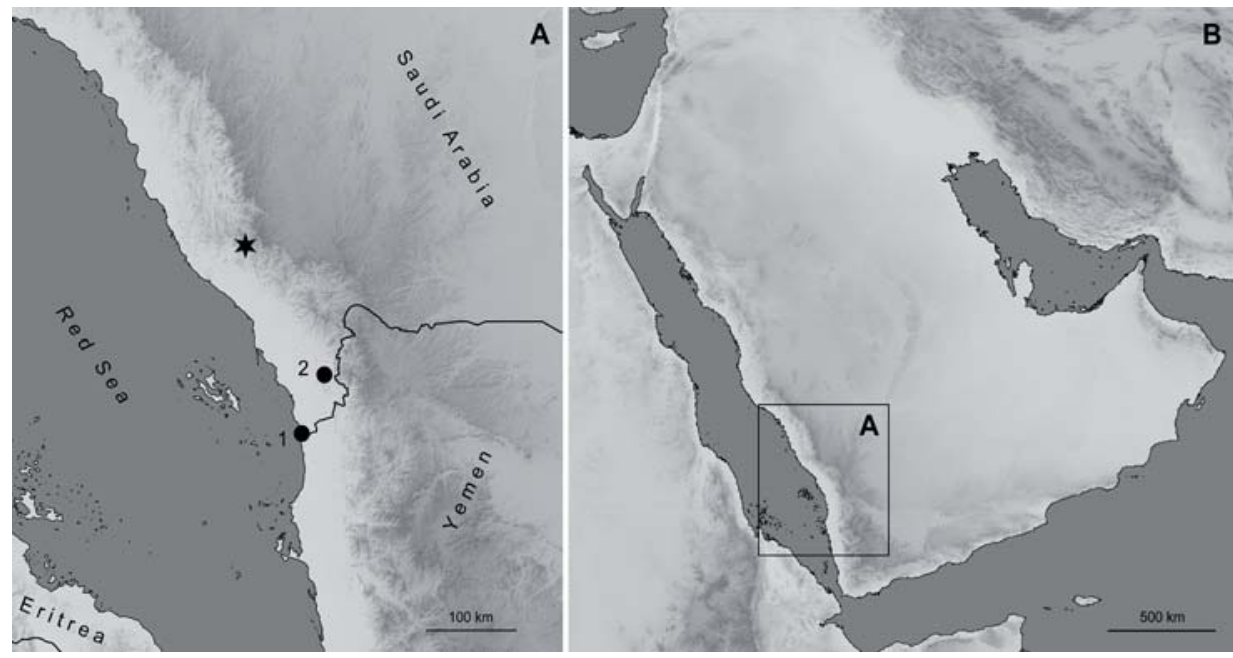

Fig. 1. Records of the Midas free-tailed bat (Mops midas) in Arabia (A) and the position of the Arabian range of this bat within the Arabian Peninsula (inset A in B); dots - previous records (1 - Al Mowassam, 2 - Al Jowa), asterisk - new record.

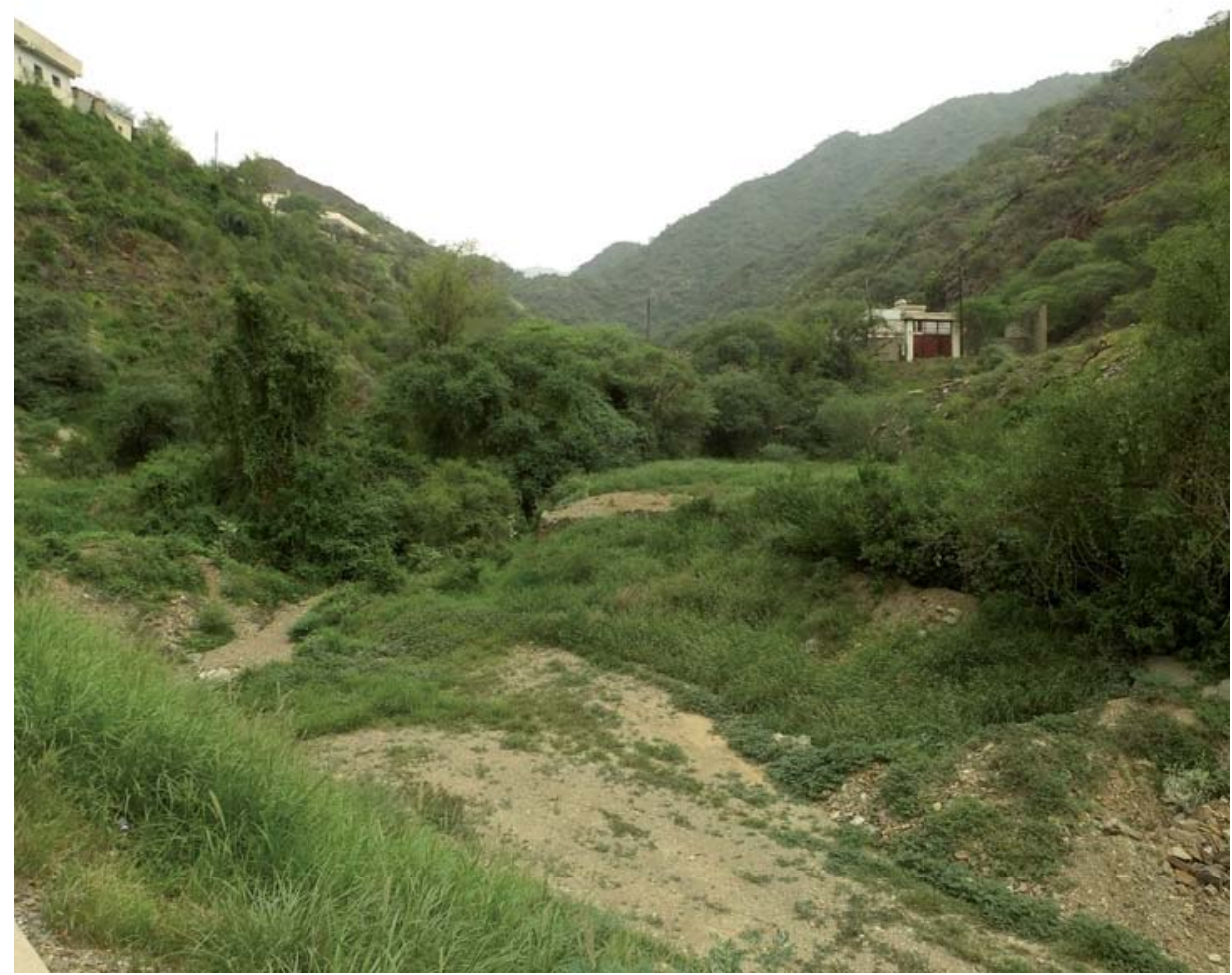

Fig. 2. The Asir Mountains, ca. 7 km south of Haqw, the locality of the new record of the Midas freetailed bat (Mops midas) in Saudi Arabia. Photo: J. Šmíd. 
Later on, Dr. Georg Basil Popov (1922-1998), a British entomologist who served for many years as a member of the Anti-Locust Bureaeu of London and supplied the BMNH with Arabian and African specimens of various animal groups, provided additional information for the locality of two individuals of Mops midas he had collected. The precise collection site was specified as near the village of Al Mowassam, Saudi Arabia (Nader 1982: 76), which is situated in the south-westernmost corner of the country [Jazan Region, $16^{\circ} 25^{\prime} \mathrm{N}, 42^{\circ} 49^{\prime} \mathrm{E}$, $115 \mathrm{~m}$ a. s. l.], just $2 \mathrm{~km}$ north of the border with Yemen (Fig. 1).

Another record of the Midas free-tailed bat was made in the village of Al Jowa [Jazan Region, $16^{\circ} 57^{\prime} \mathrm{N}, 43^{\circ} 01^{\prime} \mathrm{E}, 492 \mathrm{~m}$ a. s. l.], some $60 \mathrm{~km}$ NNE of the previous locality (Fig. 1). Three female specimens, two juveniles and a lactating adult, were collected on 7 and 8 October 1975 by the village children (Nader 1982).

Both findings were made from colonies roosting in holow trees (Hayman 1954, Nader 1982); the latter record undoubtedly represented a nursery colony.

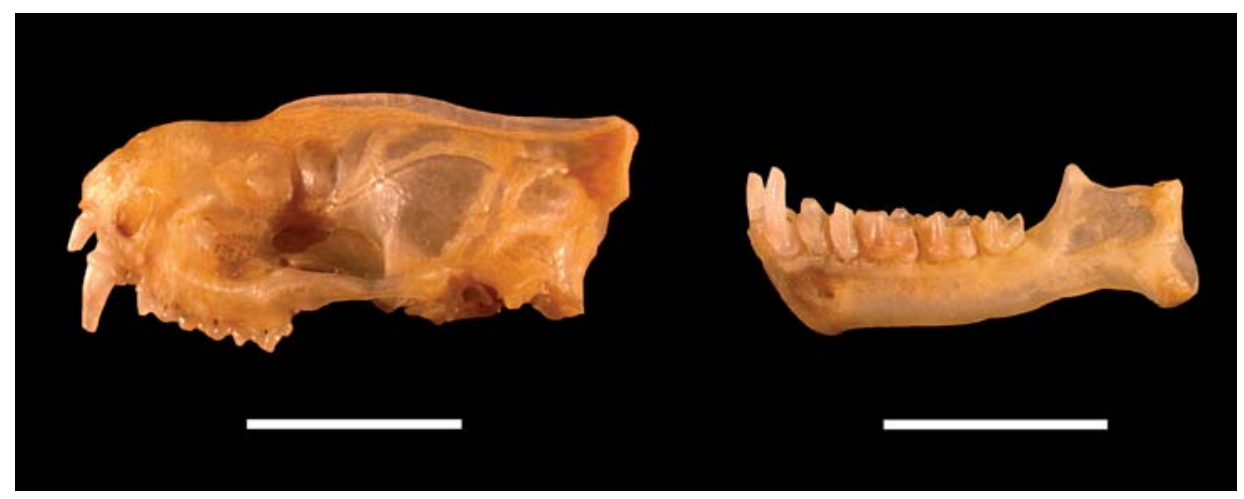

Fig. 3. Skull and mandible of the newly collected specimen of the Midas free-tailed bat (Mops midas) from near Haqw, Saudi Arabia (NMP 96880). The scale bars $=10 \mathrm{~mm}$. Photo: J. Štundl.

Herein, we report a new record of the Midas free-tailed bat from Saudi Arabia, the third finding for the country as well as for the entire Arabian Peninsula. A roadkill bat was found rather accidentally during a herpetological survey of the Asir Mountains, south-western Saudi Arabia on 21 June 2019. The individual was an adult female and was found $7 \mathrm{~km}$ north of Haqw, 'Asir Region, $18^{\circ} 09^{\prime} \mathrm{N}, 42^{\circ} 13^{\prime} \mathrm{E}, 690 \mathrm{~m}$ a. s. l. (Fig. 2). This locality lies ca. $160 \mathrm{~km}$ NNW of the closest previous site at Al Jowa (Fig. 1). Since the carcass was partly mummified and partly decomposed, the specimen was prepared as a skull and skeleton and was deposited in the collection of the National Museum (Natural History), Prague, Czech Republic (NMP 96880; Fig. 3). The skull is almost intact (only the right mandible and the right upper canine are broken), which is rather surprising given that the animal was likely hit by a car when on wings. The forearm length of the specimen is $60.8 \mathrm{~mm}$, the cranial measurements are as follows (in $\mathrm{mm}$ ): greatest length of skull 27.62, condylobasal length 25.35 , zygomatic width 16.83 , interorbital width 4.28 , neurocranium width 12.14 , mastoidal width 14.85 , neurocranium height 9.52, rostral width across upper canines (incl.) 8.24, rostral width across third upper molars (incl.) 11.62, length of upper tooth-row 10.66, condylar length of mandible 19.27, coronoid height of mandible 5.58, length of lower tooth-row 11. 74. All these values conform to the dimensions known for Mops midas (Dunlop 1999, Ratrimomanarivo et al. 2007) and are within the respective ranges confirmed by an examination of a comparative set of more than seventy specimens of the species from sub-Saharan Africa, including Ethiopia, Sudan, 
Senegal, and Namibia were examined in various museum collections by the first author.

This new record of the Midas free-tailed bat is not only the northernmost record of this rare bat in Arabia (Fig. 1), it also represents the northernmost occurrence of this species within its entire distribution range. In Africa, the northernmost locality of the Midas freetailed bat recorded so far is Berber, River Nile State, Sudan (Kock 1969, Koopman 1975). This occurrence point, situated at $18^{\circ} 02^{\prime} \mathrm{N}, 33^{\circ} 59^{\prime} \mathrm{E}$ and first reported by Hartmann (1868), is $13 \mathrm{~km}$ further south (in the latitudinal sense) compared to the newly recorded site in Saudi Arabia.

\section{Acknowledgements}

We thank Saudi Wildlife Authority for supporting the field work and Dr. Jan Štundl for his help with the skull photograph preparation. This contribution was supported by the Ministry of Culture of the Czech Republic (\# DKRVO 2019-2023/6.IX.a, 00023272).

\section{References}

Benda P., Al-Jumaily M.M., Reiter A. \& Nasher A.K., 2011: Noteworthy records of bats from Yemen with description of a new species from Socotra. - Hystrix (N. S.) 22: 23-56.

Benda P., Reiter A. \& Uhrin M., 2013: Bat fauna of the Sultanate of Oman. - Mammalian Biology 78S: 6 .

Harrison D.L., 1964: The Mammals of Arabia. Volume I. Introduction. Insectivora. Chiroptera. Primates. - London: Ernest Benn Limited, xx+192 pp.

Harrison D.L. \& Bates P.J.J., 1991: The Mammals of Africa. - Sevenoaks: Harrison Zoological Museum, $\mathrm{xv}+354 \mathrm{pp}$.

Hartmann R., 1868: Geographische Verbreitung der im nordöstlichen Afrika wild lebenden Säugethiere. - Zeitschrift der Gesellschaft für Erdkunde zu Berlin 3: 28-69.

Hayman R.W., 1954: Notes on some African bats, mainly from the Belgian Congo. - Revue de Zoologie et de Botanique Africaines 50: 277-295.

Coterill F.P.D. \& Happold M., 2013: Tadarida midas Midas free-tailed bat. - In: Happold \& M. \& Happold D.C.D. [edit.]: Mammals of Africa. Volume IV. Hedgehogs, Shrews and Bats: 518-519; Bloomsbury Publishing, London, 800 pp. https://doi. org/10.5040/9781472926944.0281

DunlopJ.,1999:Mopsmidas.-MammalianSpecies615:1-4.https://doi.org/10.2307/3504421

Kock D., 1969: Die Fledermaus-Fauna des Sudan (Mammalia, Chiroptera). - Abhandlungen der Senckenbergischen Naturforschenden Gesellschaft 521: 1-238.

Koopman K.F., 1975: Bats of the Sudan. - Bulletin of the American Museum of Natural History 154: 353-444.

Nader I.A., 1975: On the bats (Chiroptera) of the Kingdom of Saudi Arabia. - Journal of Zoology, London 176: 331-340.

Nader I.A., 1982: New distributional records of bats from the Kingdom of Saudi Arabia (Mammalia: Chiroptera). - Journal of Zoology, London 198: 69-82. https://doi. org/10.1111/j.1469-7998.1982.tb02061.x

Ratrimomanarivo F.J., Vivian J., Goodman S.M. \& Lamb J., 2007: Morphological and molecular assessment of the specific status of Mops midas (Chiroptera: Molossidae) from Madagascar and Africa. - African Zoology 42: 237-253. https://doi.org/10.3377/15627020(2007)42[237:mamaot]2. 0. co;2 